\title{
Intestinal lymphangiectasia secondary to neuroblastoma
}

\author{
RM REIFEN MD, PM SHERMAN MD FRCPC
}

RM REIFEN, PM SHERMAN. Intestinal lymphangiectasia secondary to neuroblastoma. Can J Gastroenterol 1994;8(1):49-51. An eight-month-old infant presented with a 10-day history of vomiting and diarrhea, and a one-week history of swelling of the lower extremities. Laboratory evaluations revealed hypoproteinemia and lymphocytopenia due to protein-losing enteropathy. Peroral small bowel biopsy showed intestinal lymphangiectasia. Subsequent onset of unexplained ecchymosis and obstructive jaundice resulted in additional studies which revealed an omental neuroblastoma as the underlying etiology of the infant's symptoms. This report emphasizes the importance of considering secondary, obstructive causes for lymphangiectasia and protein-losing enteropathy.

Key Words: Intestine, Lymphangiectasia, Malabsorption, Neuroblastoma, Proteinlosing enteropathy

\section{Lymphangiectasie intestinale secondaire à un neuroblastome}

RÉSUMÉ : Un nourrisson de huit mois a présenté un épisode de dix jours de vomissements et de diarrhée et un oedème d'une semaine des membres inférieurs. Les analyses de laboratoire ont révélé une hypoprotéinémie et une lymphocytopénie dues à une entéropathie avec déperdition protéique. La biopsie perorale de l'intestin grêle a révélé une lymphangiectasie intestinale. La survenue subséquente d'ecchymoses non expliquées et d'un ictère obstructif ont nécessité d'autres analyses qui ont révélé la présence d'un neuroblastome omental comme cause sous-jacente des symptômes de ce nourrisson. Ce rapport souligne l'importance de réfléchir aux causes obstructives secondaires possibles dans les cas de lymphangiectasie et d'entéropathie avec déperdition protéique.

$\mathrm{P}$ ROTEIN-LOSING ENTEROPATHY refers to a symptom complex of hypoproteinemia, hypoalbuminemia and lymphocytopenia in which there is excessive loss of plasma proteins into the lumen of the gastrointestinal tract

(1). Protein-losing enteropathy occurs in a wide variety of diseases involving different regions of the gastrointestinal tract (2).

Lymphangiectasia is a common cause of protein-losing enteropathy,

Division of Gastroenterology, Research Institute, The Hospital for Sick Children, Department of Pediatrics, University of Toronto, Toronto, Ontario

Correspondence and reprints: Dr Philip Sherman, Division of Gastroenterology (Room 1448), The Hospital for Sick Children, 555 University Avenue, Toronto, Ontario M5G IX8. Telephone (416) 813-6185, Fax (416) 813-6451

Received for publication May 13, 1993. Accepted June 24, 1993 characterized by dilated lymphatics in the lamina propria, submucosa and subserosa of the intestine (1). In this report, we present an infant with protein-losing enteropathy and intestinal lymphangiectasia due to an unusual cause: obstruction of intestinal lymphatics by a neuroblastoma present in the omentum.

\section{CASE PRESENTATION}

An eight-month-old girl of Greek heritage presented with a two-day history of vomiting and diarrhea (10 to 12 watery stools daily) 10 days prior to admission to the hospital. She was treated with clear fluids and rectal suppositories containing an antiemetic. For the seven days prior to evaluation, increasing swelling of the feet and legs was observed.

Maternal pregnancy and the delivery were unremarkable. The child's birth weight was $3100 \mathrm{~g}$. The neonatal and past histories were unremarkable. The family history was unremarkable except for a maternal history of atopy. There were no other siblings. The parents were not related other than by marriage.

The child was irritable but alert and well hydrated. Height and weight were both at the 50th percentile for age. There was evidence of perianal erythema and a scaly rash in the antecubital fossae. Heart sounds were regular and easily auscultated. The chest was clear to auscultation. The abdomen was distended with an everted umbilicus and a soft liver edge palpable $3 \mathrm{~cm}$ 


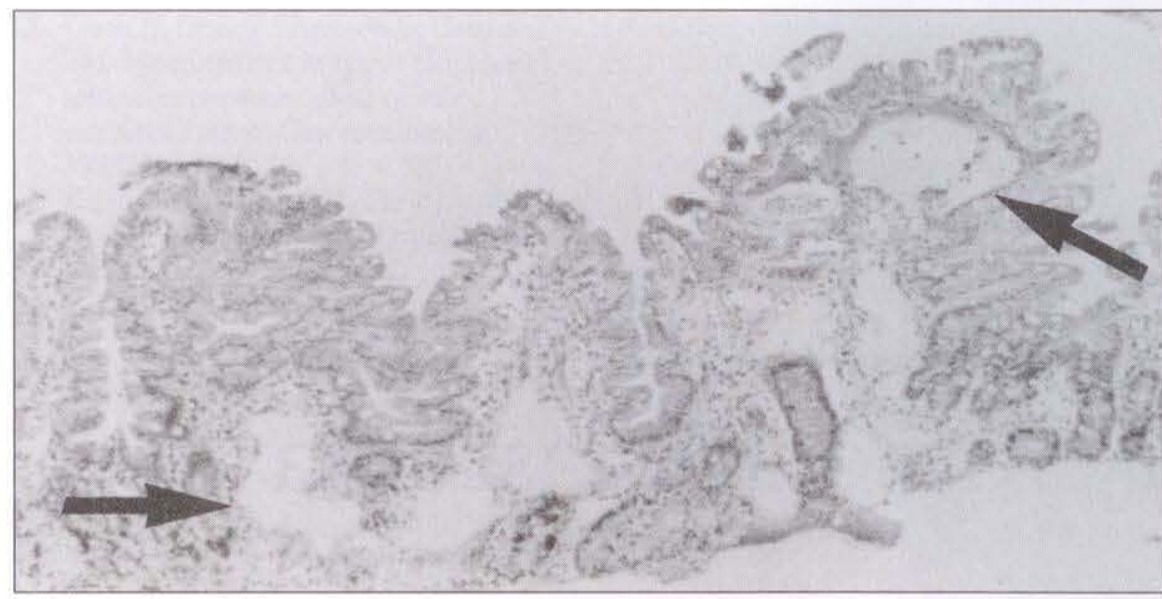

Figure 1) Small bowel biopsy showing blunted villi with distension of lymphatics (arrows). Original magnification $\times 25$

below the right costal margin. There were no palpable splenomegaly or masses. Bowel sounds were normal.

Initial laboratory values included: hemoglobin, $140 \mathrm{~g} / \mathrm{L}$ (age-specific reference range 110 to 140 ); white blood cell count, $5.4 \times 10^{9} / \mathrm{L}$ (polymorphonuclears, $\quad 2.8 \times 10^{9} / \mathrm{L}$; lymphocytes, $0.81 \times 10^{9} / \mathrm{L}$ [range 4 to 10 ]; eosinophils, $\left.0.16 \times 10^{9} / \mathrm{L}\right)$; platelet count, $409 \times 10^{9} / \mathrm{L}$ (range 150 to 400 ); and erythrocyte sedimentation rate, $3 \mathrm{~mm} / \mathrm{h}$ (normal less than $20 \mathrm{~mm} / \mathrm{h}$ ). Serum electrolytes were (in $\mathrm{mmol} / \mathrm{L}$ ): sodium, 132; potassium, 4.2; chloride, 98 ; and bicarbonate, 22 . Total protein (in $\mathrm{g} / \mathrm{L}$, normal range in brackets) was 44 (54 to 75 ); albumin, 18 (32 to 48$)$; immunoglobulin (Ig) G, 1.75 (2.73 to 16.60 ); IgM, 0.97 ( 0 to 2.16 ); and $\operatorname{IgA}, 0.10$ ( 0 to $1.00)$. Liver function tests included (normal range in brackets): alanine aminotransferase, $23 \mathrm{IU} / \mathrm{L}$ (less than 40); aspartate, $111 \mathrm{IU} / \mathrm{L}$ (less than 40 ); alkaline phosphatase, $103 \mathrm{IU} / \mathrm{L}$ (185 to 555); total bilirubin, $18 \mu \mathrm{mol} / \mathrm{L}$ (less than 18); and prothrombin time, $12.3 \mathrm{~s}$ (10.5 to 13.5$)$. Serum calcium was (in $\mathrm{mmol} / \mathrm{L}$, normal range in brackets) 1.99 (2.25 to 2.74 ) and phosphate was 1.11 (1.3 to 220). Triglyceride was (in $\mathrm{mmol} / \mathrm{L}$, normal range in brackets)
1.05 ( 0.34 to 1.58$)$ and cholesterol was 2.90 (less than 4.91). Urinalysis was unremarkable without evidence of proteinuria. A chest radiograph, electrocardiogram and two-dimensional echocardiogram were normal. A barium meal was normal without evidence of malrotation. Stool samples examined by culture and ova-and-parasite analysis were negative. The alpha- 1 antitrypsin clearance was $40 \mathrm{~mL} /$ day (normal range less than 22).

A peroral duodenal biopsy documented lymphangiectasia (Figure 1), and the child was placed on a mediumchain triglyceride containing infant formula as therapy.

However, the child subsequently developed periorbital ecchymosis and jaundice accompanied with abnormal liver enzyme tests and platelet count of $311 \times 10^{9} / \mathrm{L}$. Further investigations included a 24 h urine collection for excretion of vannilmandelic acid - 127 $\mu \mathrm{mol} /$ day (normal value for age younger than 12 months) and homovanillic acid $-65 \mu \mathrm{mol} / \mathrm{mol}$ creatinine (normal less than 20). Computerized axial tomography of the abdomen demonstrated a mesenteric and omental mass with calcifications that extended in the retroperitoneal space (Figure 2). A cholecystocholangiogram showed the omental mass impinging on the ex-

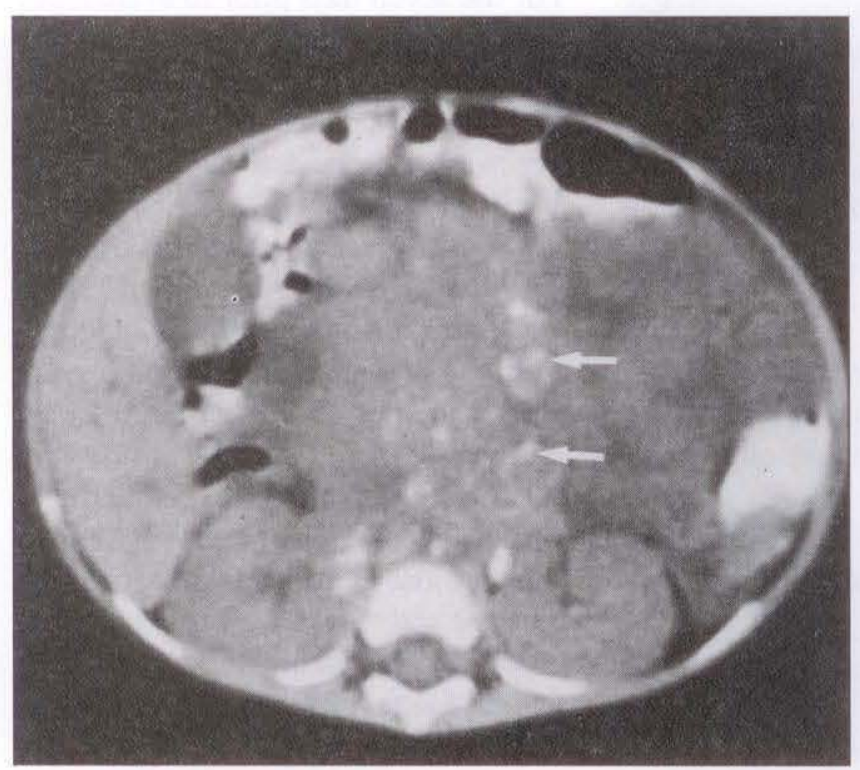

Figure 2) Computerized axial tomography scan of the abdomen showing a retroperitoneal mass with calcifications (arrows) extending anteriorly into the root of the mesentery

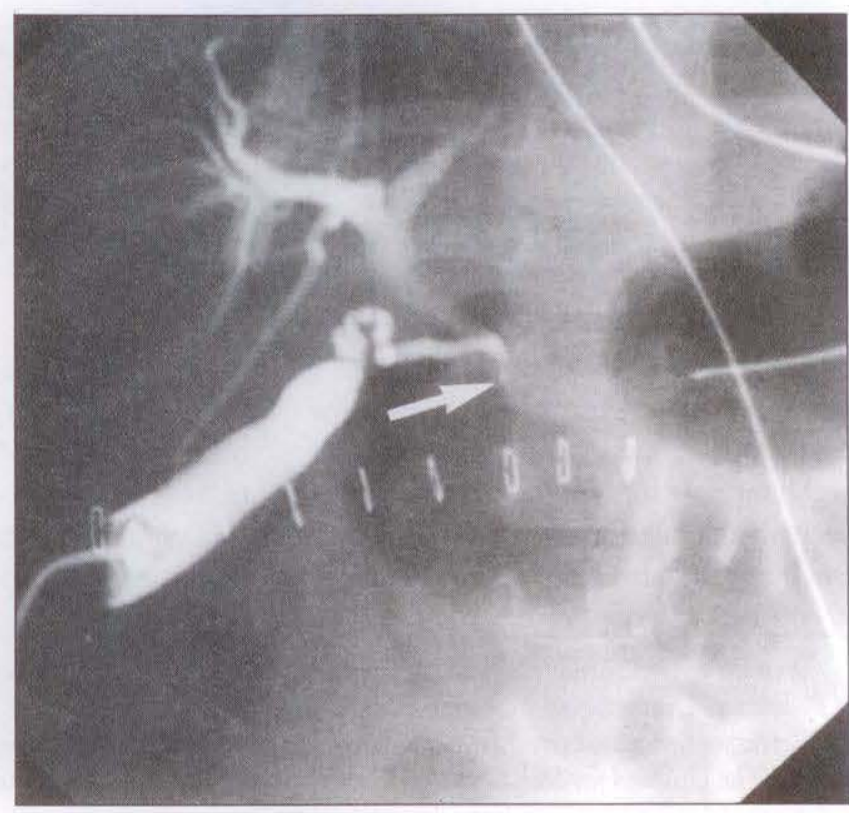

Figure 3) Cholecystocholangiogram showing a complete obstruction of the common bile duct (arrow) 
tra-hepatic biliary tract with obstruction to flow (Figure 3). A bone scan showed retro-orbital metastatic lesions. A laparotomy was performed to provide a histological diagnosis. Histological review of the biopsy showed a neuroblastoma with features of early differentiation consistent with the 'stroma-poor' classification of Shimada et al (3). The protein-losing enteropathy resolved with successful treatment of the tumour.

\section{DISCUSSION}

Enteric losses of protein in our patient were consistent with intestinal lymphangiectasia, and this diagnosis was confirmed by the presence of dilated lymphatic channels in the mucosa and submucosa of the duodenum. Intestinal lymphangiectasia is characterized by dilated intestinal submucosal and subserosal lymphatics, proteinlosing enteropathy, hypoalbuminemia, hypoproteinemic edema and lymphocytopenia. The disease can vary widely in both the clinical spectrum of manifestations and its severity. Lymphangiectasia can be limited to the

ACKNOWLEDGEMENTS: P Sherman is the recipient of a Career Scientist Award from the Ontario Ministry of Health

\section{REFERENCES}

1. Vardy PA, Lebenthal E, Shwachman $\mathrm{H}$. Intestinal lymphangiectasia: A reappraisal. Pediatrics 1975;55:842-51.

2. Waldmann TA. Protein-losing enteropathy. Gastroenterology 1966;50:422-43.

3. Shimada H, Chatten J, Newton WA $\mathrm{Jr}$, et al. Histopathologic prognostic factors in neuroblastic tumors: Definition of subtypes of intestine or involve multiple organs, such as occurs in Noonan syndrome, Turner syndrome and Milroy disease (4). When confined to the intestinal tract, lymphangiectasia can be due to primary or secondary causes. Primary lymphangiectasia is presumed to be due to a congenital lymphatic anomaly (1).

Secondary cause of intestinal lymphangiectasia are related to obstruction of mesenteric lymph nodes and lymphatic channels as is seen, for example, in malrotation (5). Protein-losing enteropathy has also been reported in association with malignant tumours usually primary tumours of the gastrointestinal tract as well as in lymphosarcoma and Hodgkin's disease (6). Protein-losing enteropathy and lymphangiectasia due to lymphatic obstruction by the tumour mass of a neuroblastoma have been reported previously in two other children $(7,8)$. Neuroblastoma, a common tumour of infants less that one year of age (9), originates from amine precursor uptake and decarboxylation cells in the neural crest (10). Metastases from neuroblastoma characteristically migrate along

ganglioneuroblastoma and an age-linked classification of neuroblastomas. J Natl Cancer Inst 1984;73:405-16.

4. Hilliard RI, McKendry JBJ, Phillips MJ. Congenital abnormalities of the lymphatic system: A new clinical classification. Pediatrics 1990;86:988-94.

5. Brandt ML, Pokorny WJ, McGill CW, Harberg FJ. Late presentations of midgut malrotation in children. Am J Surg 1985;150:767-71.

6. Waldmann TA, Broder S, Strober W. Protein-losing enteropathies in paravertebral lymph nodes (10), which potentially could obstruct the lymphatic flow. Over the past 10 years, seven children were diagnosed with intestinal lymphangiectasia at The Hospital for Sick Children in Toronto, Ontario. The only child with secondary lymphangiectasia in this group was the presented patient.

\section{CONCLUSIONS}

This case report emphasizes that small bowel biopsy, considered a definitive diagnostic procedure for intestinal lymphangiectasia (6), does not differentiate primary causes from secondary etiologies. Therefore, distinction of primary, from secondary, causes of lymphatic obstruction should be part of the evaluation of all patients presenting with protein-losing enteropathy due to lymphangiectasia. In children, additional investigations (in the authors' estimation) should include measurement of urinary catecholamine levels, abdominal ultrasonography, a barium meal to localize the ligament of Treitz and, possibly, computerized tomography of the abdomen.

malignancy. Ann NY Acad Sci 1974;230:306-17.

7. Gerdes JS, Katz AJ. Neuroblastoma appearing as protein-losing enteropathy. Am J Dis Child 1982;136:1024-5.

8. Schussheim A. Protein-losing enteropathies in children. Am J Gastroenterol 1972;58:124-32.

9. Bader JL, Miller RW. US cancer incidence and mortality in the first year of life. Am J Dis Child 1979;133:157-9.

10. Smith EI, Castleberry RP. Neuroblastoma. Curr Probl Surg 1990;27:579-620. 


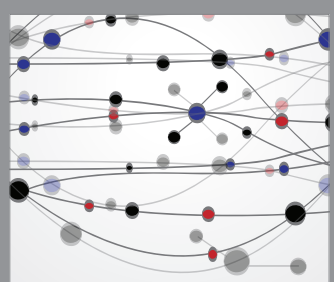

The Scientific World Journal
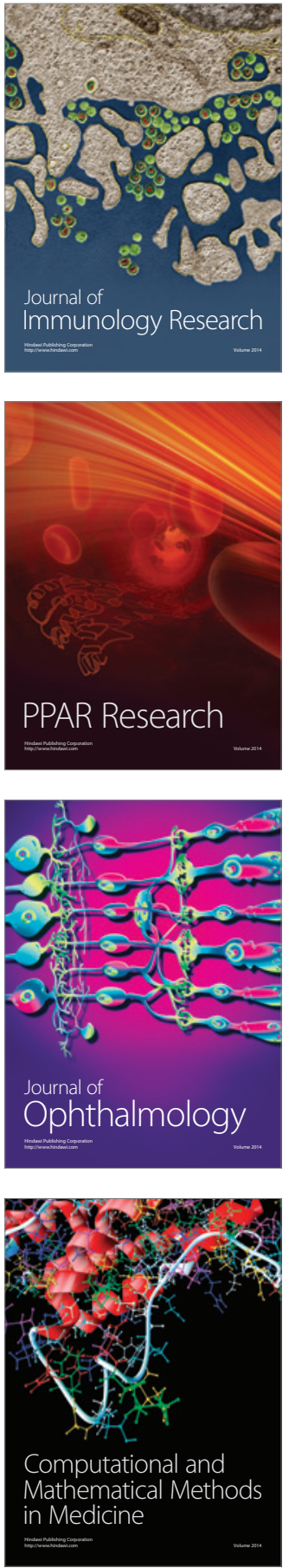

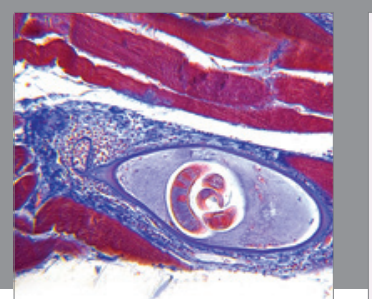

Gastroenterology Research and Practice

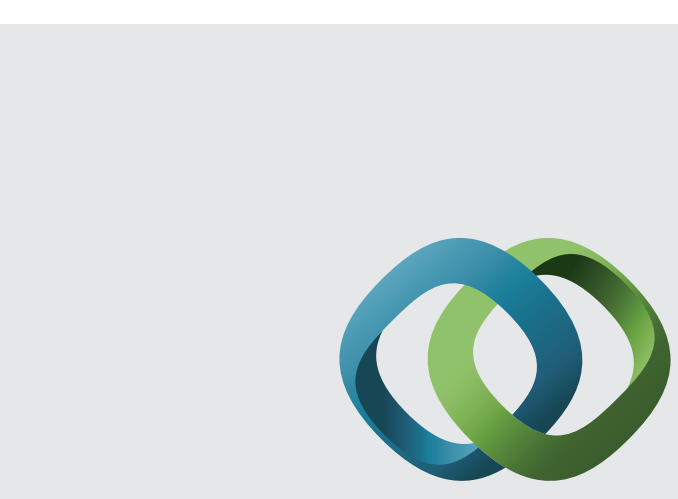

\section{Hindawi}

Submit your manuscripts at

http://www.hindawi.com
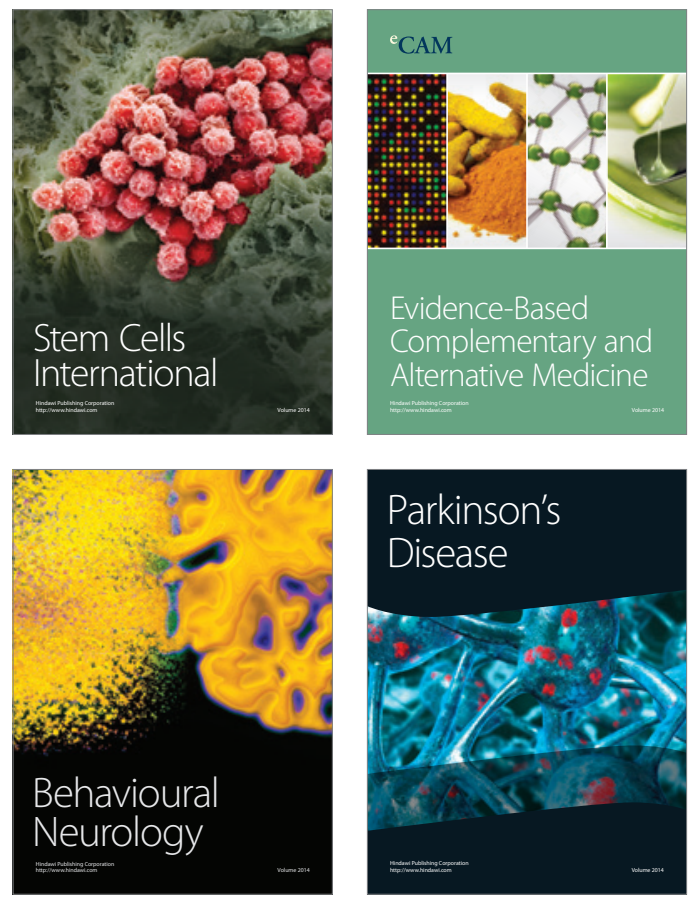
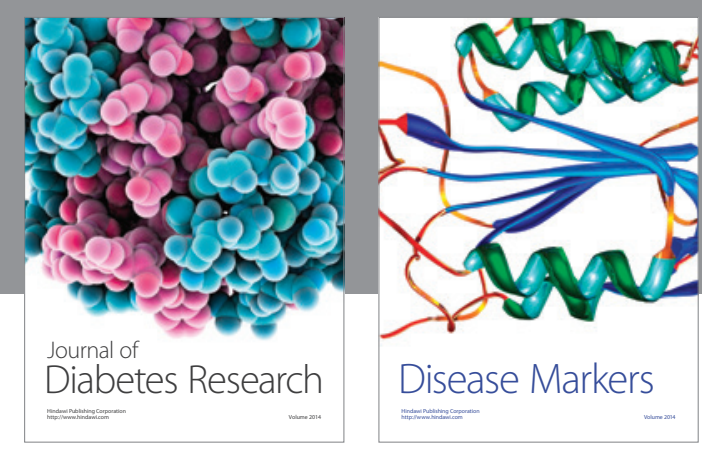

Disease Markers
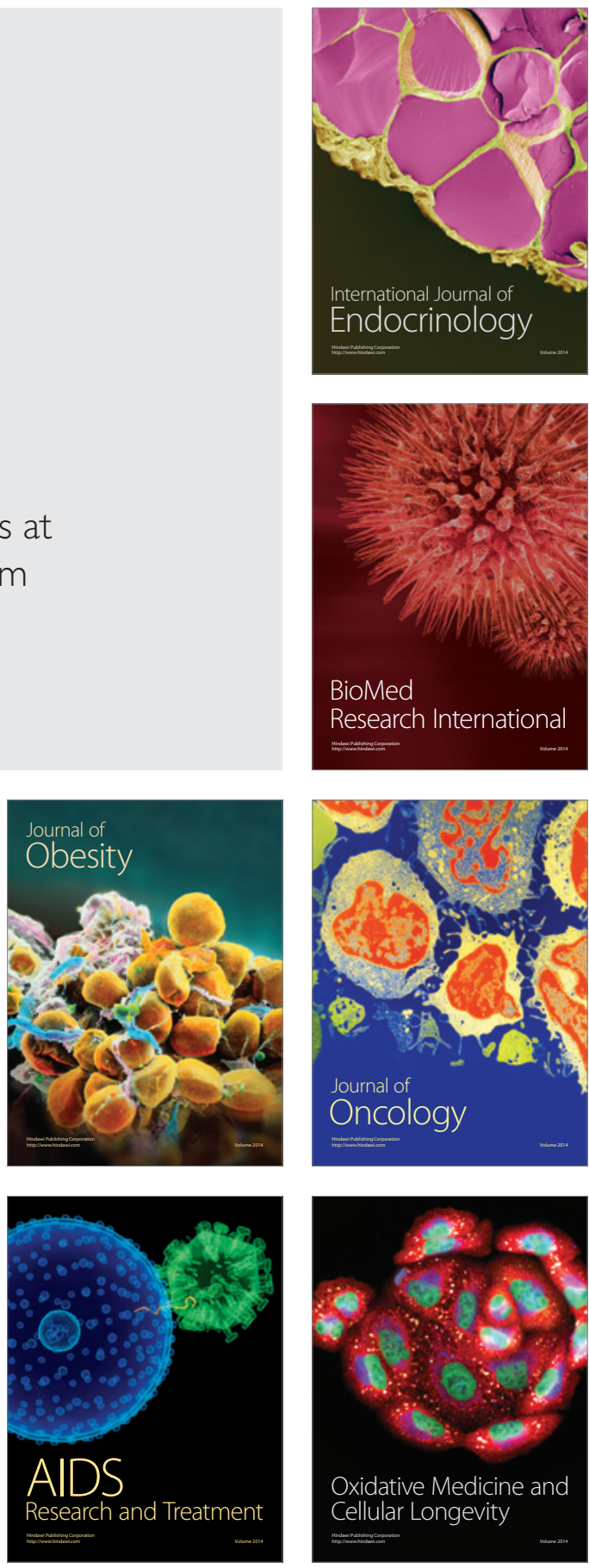